Research

\title{
Serum concentration of Selenium in healthy individuals living in
}

Tehran

\author{
R Safaralizadeh, GA Kardar, Z Pourpak, M Moin, A Zare and S Teimourian*
}

Address: Immunology, Asthma \& Allergy Research Institute, Children Medical Center, Tehran University of Medical Sciences, Tehran, P.O. Box: 14185-938, I.R.Iran

Email: R Safaralizadeh - ralizadeh@nrcgeb.ac.ir; GA Kardar - gakardar@nrcgeb.ac.ir; Z Pourpak - zpourpak@hbi.ir; M Moin - mmoin@sina.tums.ac.ir; A Zare - ahadzr@gmail.com; S Teimourian* - teimourian@ibb.ut.ac.ir

* Corresponding author

Published: 14 November 2005

Nutrition Journal 2005, 4:32 doi:10.1/86/1475-289/-4-32

This article is available from: http://www.nutritionj.com/content/4/I/32

(C) 2005 Safaralizadeh et al; licensee BioMed Central Ltd.

This is an Open Access article distributed under the terms of the Creative Commons Attribution License (http://creativecommons.org/licenses/by/2.0), which permits unrestricted use, distribution, and reproduction in any medium, provided the original work is properly cited.
Received: 08 June 2005

Accepted: 14 November 2005

\begin{abstract}
Objective: To investigate whether daily diet provides adequate selenium intake in healthy men and women living in Tehran, Iran.

Method: Serum level of selenium was determined in 184 healthy individuals of both genders. The samples were divided into two age groups, adults and children, for analysis. The serum level of selenium was determined using hydride generation and flame atomic absorption spectroscopy.
\end{abstract}

Results: The mean and standard deviation of serum selenium levels in children (I-I6 years) was $84.3 \pm \mathrm{II} \mu \mathrm{g} / \mathrm{l}$ and there was no significant difference between genders in this group. In adults (older than 16 years) the mean serum selenium level was $100.6 \pm 13 \mathrm{SD} \mu \mathrm{g} / \mathrm{l}$; among women the mean was $93.9 \pm 14 \mathrm{SD} \mu \mathrm{g} / \mathrm{l}$ and among men it was $102.2 \pm 12 \mathrm{SD} \mu \mathrm{g} / \mathrm{l}$. The mean selenium level in men was higher than in women and data analysis showed a significant difference between them $(P<$ 0.005). There was also a positive correlation between higher selenium serum concentration and age in men $(P<0.00 \mathrm{I})$. Daily intake of selenium in men and women was calculated to be $67 \mu \mathrm{g}$ and 62. I $\mu \mathrm{g}$ respectively.

Conclusion: Our results show that the serum concentration of selenium in an Iranian population is similar to other nationalities in the Middle East, particularly Saudi Arabia.

\section{Introduction}

Selenium (Se) plays a key role in the maintenance of normal health in human populations [1]. The cellular biochemistry of Selenium involves the expression of a variety of selenoproteins. Selenium is part of the active site of glutathione peroxidase (GSH-Px), an antioxidant enzyme [2]. It has been demonstrated that, when taken as a supplement, Selenium modulates the cellular response to oxi- dative stress, inducing a faster restoration of the endogenous antioxidative defense system against the production of reactive oxygen species [3]. Glutathion peroxidase controls the interacellular level of hydrogen peroxide, reducing the formation of reactive oxygen species that can induce lipid peroxidations with consequent damage to the cellular membranes [4]. Epidemiological studies suggest a low intake of Selenium might predispose 
Table I: Age and sex of the studied individuals with corresponding selenium levels $(\mu \mathrm{g} / \mathrm{l})$

\begin{tabular}{|c|c|c|c|c|c|c|}
\hline Age & Sex & $\mathrm{n}$ & Min & Max & Mean \pm SD & $\begin{array}{l}\text { Reference Range } \\
\quad(95 \% \mathrm{Cl})\end{array}$ \\
\hline \multirow[t]{2}{*}{$1-16 Y$} & $\mathrm{~F}$ & 22 & 66 & 105 & $85.0 \pm 10.8$ & $63-106$ \\
\hline & $M$ & 32 & 58 & 105 & $83.7 \pm 11.1$ & $63-106$ \\
\hline \multirow[t]{2}{*}{ Over16Y } & $\mathrm{F}$ & 24 & 74 & 125 & $93.9 \pm 13.6$ & $67-121$ \\
\hline & $M$ & 106 & 75 & 134 & $102.1 \pm 12.2$ & $79-126$ \\
\hline
\end{tabular}

Y: Year, M: Male, F: Female, SD: Standard Deviation

$P$-value less than 0.05 is statistically significant

an individual to an increased incidence of cardiovascular disorders [5]. There is increasing evidence that selenium deficiency may have several serious short- and long-term medical implications, including impaired immune response, or even cancer [6]. An experimental study has shown that an increase in selenium level is associated with decreased cancer mortality [7]. The recommended dietary allowance of Selenium in the USA is $55 \mu \mathrm{g} /$ day for women and $70 \mu \mathrm{g} /$ day for men. In some regions of the world such as Finland, New Zealand, the East coast of the United States of America and China the content of Selenium in soil is remarkably low [4]. Therefore Selenium levels in the serum of populations throughout the world vary from $41.7 \mu \mathrm{g} / \mathrm{l}$ in Finland to $158.2 \mu \mathrm{g} / \mathrm{l}$ in Canada [8]. There is currently no information of selenium intake and serum levels in the Iranian population. The aim of our study was therefore to evaluate serum levels of Selenium to find out whether daily diet provides adequate selenium intake to maintain the health of men and women living in Tehran.

\section{Materials and methods \\ I. Subject selection}

Serum samples were collected from 184 random inhabitants of Tehran. An informed consent was acquired, according to the guidelines from the Tehran university research ethic committee. Some of the samples were collected from excessive serum residues of blood taken from children who were referred for routine laboratory check up at the Children's Medical Center. All the samples were tested to rule out HIV, HBV and HCV contamination. Blood samples were left to coagulate spontaneously.

\section{Determination of serum selenium}

Blood samples $(3 \mathrm{ml})$ were centrifuged at $3000 \times \mathrm{g}$ for 5 minutes. The clean serum was stored at $-70^{\circ} \mathrm{C}$ until the time of analysis. All glassware and bottles used for the isolation of serum and for analysis were previously soaked in diluted nitric acid (10\%) and rinsed thoroughly with deionized water. This procedure was followed in order to exclude the possibility of contamination with trace elements. Serum $(500 \mu \mathrm{l})$ was aliquoted into a vessel-tube for mineralization with $3 \mathrm{ml}$ of $\mathrm{HNO}_{3} / \mathrm{HCLO}_{4}(4: 1 \mathrm{v} / \mathrm{v})$. The temperature of this mixture was slowly increased to $175^{\circ} \mathrm{C}$ until fumes of $\mathrm{HCLO}_{4}$ appeared. The mixture was then heated according to the following (temperature/ time) scheme: $175^{\circ} \mathrm{C} / 60 \mathrm{~min}, 200^{\circ} \mathrm{C} / 60 \mathrm{~min}$ and finally $250^{\circ} \mathrm{C}$ for $60 \mathrm{~min}$. The mixture was then left to cool down to room temperature. HCL $6 \mathrm{~N}(10 \mathrm{ml})$ was added and heated to $170^{\circ} \mathrm{C}$ for $30 \mathrm{~min}$ to reduce the Se (VI) to Se (IV). After cooling to room temperature, Se concentration was determined using the hydride generation atomic absorption spectrometry (Atomic absorption spectrometer Shimadzu, AA-680). Sodium borohydride solution (3 $\mathrm{g} \mathrm{NaBH}_{4}, 1 \mathrm{~g} \mathrm{NaOH}$ in $100 \mathrm{ml}$ of mili-Q water) was used as a reducing agent. All samples and standards were analysed in duplicate. The accuracy of the procedure was evaluated by analyzing commercially available samples of lyophilized human serum seronorm ${ }^{\mathrm{TM}}$ trace element serum, level 1, M10181 indicating a recommended value of $81 \mu \mathrm{g} / \mathrm{l}$, and seronorm ${ }^{\mathrm{TM}}$ trace element serum, level 2, NO0371 indicating a recommended value of $136 \mu \mathrm{g} / \mathrm{l}$.

\section{Statistical analysis}

Kolmogorov-Smirnov tests were carried out for normal distribution. The reference range for serum selenium was determined as the $95 \%$ confidence interval (CI) of means. Differences in selenium concentration between the male and female populations were analyzed with the MannWhitney U-test. P-values of less than 0.05 were considered significant.

\section{Results}

The studied individuals were all healthy, non-smokers. Volunteer medical history and physical examination ruled out the presence of current disease in the studied individuals. None of the individuals showed any digestive symptoms indicative of nutrient malabsorption. The mean and standard deviation of the individual selenium levels in children (age $1-16$ ) was $84.2 \pm 11 \mu \mathrm{g} / \mathrm{l}$, which was $85.1 \pm$ $10.8 \mu \mathrm{g} / \mathrm{l}$ among females and $83.7 \pm 11.2 \mu \mathrm{g} / \mathrm{l}$ among males. The mean serum selenium level in adults (over 16 years) was $100.6 \pm 12.9 \mu \mathrm{g} / \mathrm{l}$, for adult women the mean 
Table 2: Sensitivity and precision of the assay

\begin{tabular}{lllll}
\hline Material & \multicolumn{2}{l}{ Concentration } & Accuracy (\%) & Precision R.S.D(\%) \\
\cline { 2 - 3 } & Certified & Measured & \\
\hline Seronorm $^{\mathrm{TM}}$ Trace Element Serum (Level I, MI018I) & $81 \pm 1.5$ & $80.4 \pm 2.7$ & 99.3 & 3.36 \\
Seronorm $^{\mathrm{TM}}$ Trace Element Serum (Level 2, NO037I) & $136 \pm 4.5$ & $135 \pm 3.8$ & 99.2 & 2.81 \\
\hline
\end{tabular}

R.S.D: relative standard deviation

was $93.9 \pm 13.6 \mu \mathrm{g} / \mathrm{l}$ and for adult men was $102.1 \pm 12.3$ $\mu \mathrm{g} / \mathrm{l}$ (Table 1). The accuracy and precision of the methods used for selenium analysis are summarized in Table 2.

\section{Discussion}

Selenium is an essential mineral in human nutrition. Natural selenium present in the diet of humans is in the form of organic seleno-proteins such as selenomethionine and seleno-cysteine. Foods such as fish and whole grain cereals are especially rich in organic selenium compounds [11]. Selenium in cereals is primarily in the form of selenomethionine. This naturally occurring amino acid is the most important nutritional form of selenium.

Deficiencies of selenium contribute to the prevalence and severity of iodine deficiency disorders which are the most important and well-known global nutritional problems, primarily in less developed countries [12]. Iodine deficiency in childhood impairs neuromotor and intellectual development, with an average reduction in the intelligence quotient of 10 points [13]. Selenium is required in thyroid metabolism, converting inactive thyroid hormone into active thyroid hormone [14]. It has been shown that in goitrous children who are both Se and iodine deficient, major Se deficiency partially blunts thyroid response to iodine supplementation [15]. The mean serum Se level for healthy children (age 1-16) observed in this study was $84.2 \pm 11 \mu \mathrm{g} / \mathrm{l}$ with no significant difference between sexes

Table 3: Comparison of the mean serum levels of selenium, among children from different countries (as mentioned previously [10])

\begin{tabular}{lll}
\hline Country & Overall mean $(\mu \mathrm{g} / \mathrm{I})$ & Age range (years) \\
\hline Austria & 48 & $\mathrm{I}-15$ \\
Finland & 58.5 & $\mathrm{I}-15$ \\
Belgium & 60 & $\mathrm{I}-15$ \\
Germany & 65.5 & $\mathrm{I}-18$ \\
France & 67 & $3-16$ \\
England & 74.2 & $2-16$ \\
Iran & 84.3 & $\mathrm{I}-16$ \\
Japan & 84.5 & $\mathrm{I}-15$ \\
Slovenia & 85 & $\mathrm{I}-13$ \\
Turkey & 89 & $\mathrm{I}-16$ \\
US & 106 & $\mathrm{I}-18$ \\
Canada & 126 & $\mathrm{I}-9$
\end{tabular}

$(p=0.659)$. Table 3 shows the mean serum Se level of Iranian children compared to children from different countries.

The mean serum Se level for adults observed in this study was $100.6 \pm 12.8 \mu \mathrm{g} / \mathrm{l}$, which was similar to the one reported in a survey in Saudi Arabia [16]. In the Nutritional Prevention of Cancer (NPC) Trial [17], a Selenium level of $80 \mathrm{ng} / \mathrm{mL}$ is considered the minimum level of plasma selenium necessary in the bloodstream for maximum production of selenoproteins (glutathione peroxidases, thioredoxin reductase, etc.).

Our results show that in adults there is a significant difference between men and women $(p<0.005)$ with a higher concentration of selenium in men. This suggests a sexlinked hormonal influence over serum level of selenium. It has previously been shown that selenium is essential for spermatogenesis [18]. This trace element is present in the protein of the capsule surrounding the sperm mitochondria and may have a structural function [19]. Our data also show a positive correlation between a higher concentration of selenium in serum and age in men $(\mathrm{P}<0.001)$.

Table 4 summaries the selenium serum levels in the Iranian population in comparison with different countries. It is higher than levels calculated for Finland and other

Table 4: Comparison of the mean serum levels of selenium, among adults from different countries (as mentioned previously $[9,11])$

\begin{tabular}{ll}
\hline Country & Overall mean $(\mu \mathbf{g} / \mathbf{l})$ \\
\hline Finland (Helsinki) & 41.7 \\
New Zealand (Dunedin) & 47.2 \\
Brazil (Rio de Janeiro) & 73.2 \\
W. Germany (Mainz) & 81.1 \\
Sweden (lund) & 85.0 \\
Italy (Rome) & 89.8 \\
Japan (Hiroshima) & 97.6 \\
Iran (Tehran) & 100.3 \\
Saudi Arabia & 102.5 \\
US (Mort.Gr.) & 110.2 \\
England (Southampton) & 115.7 \\
Canada (Toronto) & 158.3 \\
\hline
\end{tabular}


countries where soil is poor in selenium content. By using the medium correlation factor (1.51) as introduced by Navarro et al., to estimate the daily intake of nutrients, the daily intake of Se was calculated as $62.19 \mu \mathrm{g}$ in the female and $67 \mu \mathrm{g}$ in the male populations [20].

Considering the American RDA, which recommends a daily Se intake of $50 \mu \mathrm{g}$ for women and $70 \mu \mathrm{g}$ for men, it seems that the normal Iranian diet has an adequate content of selenium for both genders.

Tehran, the capital of Iran, is located in the north of the country and has a population of approximately fifteen million people, representing a large proportion of the country's total population, estimated to be seventy five million people. The diversity of nourishment sources, regional variation and different ethnic diets makes it difficult to extend these results to the whole population.

\section{Acknowledgements}

This study was supported in part by a grant from the Tehran University of Medical Sciences. The authors would like to acknowledge Dr. Verity A.

Cadd at Oxford University for kind revision of the manuscript.

\section{References}

I. Savarino L, Granchi D, Ciapetti G, Cenni E, Ravaglia G, Forti P, Maioli F, Mattioli R: Serum concentrations of zinc and selenium in elderly people: results in healthy nonagenarians/centenarians. Exp Gerontol 200I, 36:327-39.

2. Rotruck JT, Pope AL, Ganther HE, Swanson AB, Hafeman DG, Hoekstra WG: Selenium: biochemical role as a component of glutathione peroxidase. Science 1973, 179:588-90.

3. Jozanov-Stankov O, Demajo M, Djujic I, Mandic M: Selenium intake as a modulator of responsiveness to oxidative stress. J Environ Pathol Toxicol Oncol 1998, 17:251-7.

4. Burk RF, Levander OA: Selenium. In Modern nutrition in health and disease 9th edition. Edited by: Shils ME, Olson J, Shike M. Lippincott Williams \& Wilkins, Baltimore; 1999:265-276.

5. Salonen JT, Alfthan G, Huttunen JK, Pikkarainen J, Puska P: Association between cardiovascular death and myocardial infarction and serum selenium in a matched-pair longitudinal study. Lancet 1982, 2: 175-9.

6. Kohrle J, Brigelius-Flohe R, Bock A, Gartner R, Meyer O, Flohe L: Selenium in biology: facts and medical perspectives. Biol Chem 2000, 38 I:849-64.

7. Gupta S, Narang R, Krishnaswami K, Yadav S: Plasma selenium level in cancer patients. Indian J Cancer 1994, 31:192-7.

8. Lockitch G: Selenium: clinical significance and analytical concepts. Crit Rev Clin Lab Sci 1989, 27:483-54I.

9. Muntau AC, Streiter M, Kappler M, Roschinger W, Schmid I, Rehnert A, Schramel P, Roscher AA: Age-related reference values for serum selenium concentrations in infants and children. Clin Chem 2002, 48:555-60.

10. da Cunha S, Filho FM, Antelo DS, de Souza MM: Serum sample levels of selenium and copper in healthy volunteers living in Rio de Janeiro city. Sci Total Environ 2003, 30 I:5 I-4.

II. Schrauzer GN, Katz RN: Reductive dechlorination and degradation of mirex and kepone with Vitamin B I2. Bioinorg Chem 1978, 9:123-43.

12. Vanderpas JB, Contempre B, Duale NL, Goossens W, Bebe N, Thorpe R, Ntambue K, Dumont J, Thilly CH, Diplock AT: lodine and selenium deficiency associated with cretinism in northern Zaire. Am J Clin Nutr 1990, 52:1087-93.

13. DeLong GR, Leslie PW, Wang SH, Jiang XM, Zhang ML, Rakeman M, Jiang JY, Ma T, Cao XY: Effect on infant mortality of iodination of irrigation water in a severely iodine-deficient area of China. Lancet 1997, 350:77/-3.
14. Napolitano G, Bonomini M, Bomba G, Bucci I, Todisco V, Albertazzi $A$, Monaco $F$ : Thyroid function and plasma selenium in chronic uremic patients on hemodialysis treatment. Biol Trace Elem Res 1996, 55:22I-30.

15. Zimmermann MB, Adou P, Toressani T, Zeder C, Hurrel RF: Effect of oral iodized oil on thyroid size and thyroid hormone metabolism in children with concurrent selenium and iodine deficiency. Eur J Clin Nutr 2000, 54:209-I3.

16. Raines DA, Kinsara AJ, Eid Fawzy M, Vasudevan S, Mohamed GE, Legayada ES, Al-Rawithi S, El-Yazigi A: Plasma and urinary selenium in Saudi Arabian patients with dilated cardiomyopathy. Biol Trace Elem Res 1999, 69:59-68.

17. Duffield-Lillico AJ, Reid ME, Turnbull BW, Combs GF Jr, Slate EH, Fischbach LA, Marshall JR, Clark LC: Baseline characteristics and the effect of selenium supplementation on cancer incidence in a randomized clinical trial: a summary report of the Nutritional Prevention of Cancer Trial. Cancer Epidemiol Biomarkers Prev 2002, I I:630-639.

18. Wu SH, Oldfield JE, Whanger PD, Weswig PH: Effect of selenium, vitamin $E$ and antioxidants on testicular function in rats. Biol Reprod 1973, 8:625-9.

19. Hansen JC, Deguchi Y: Selenium and fertility in animals and man - a review. Acta Vet Scand 1996, 37:19-30.

20. Navarro M, Lopez H, Ruiz ML, Gonzalez S, Perez V, Lopez MC: Determination of selenium in serum by hydride generation atomic absorption spectrometry for calculation of daily dietary intake. Sci Total Environ 1995, 175:245-52.
Publish with BioMed Central and every scientist can read your work free of charge

"BioMed Central will be the most significant development for disseminating the results of biomedical research in our lifetime. " Sir Paul Nurse, Cancer Research UK

Your research papers will be:

- available free of charge to the entire biomedical community

- peer reviewed and published immediately upon acceptance

- cited in PubMed and archived on PubMed Central

- yours - you keep the copyright

Submit your manuscript here:

http://www.biomedcentral.com/info/publishing_adv.asp
BioMedcentral 